\title{
ResearchArticle
}

\section{Studies on anther culture in tomato}

\author{
U.B. SHERE AND N.R. MAIRAN
}

\section{SUMMARY}

Anther or pollen culture have been used in mutation and $F_{1}$ hybrid breeding programme in many plant species. In order to get haploid plants, three tomato varieties were used in this study. Anther were removed from 2-4 mm, 5-6 mm and 8-10 $\mathrm{mm}$ length tomato flowers. Two different nutrient media were investigated to get callus. $\mathrm{N}_{6}$ medium $+2 \mathrm{mg} / \mathrm{L} \mathrm{NAA}+1 \mathrm{mg} /$ L Kinetin was most efficient medium for anther callus growth. Calluses were subcultured but calli did not show any response for further callus growth and haploid plantlets were not obtained.

Key Words : Anther culture, Callus formation, Tomato

How to cite this article : Shere, U.B. and Mairan, N.R. (2017). Studies on anther culture in tomato. Internat. J. Plant Sci., 12 (2): 131-134, DOI: 10.15740/HAS/IJPS/12.2/131-134.

Article chronicle : Received : 31.12.2016; Revised : 26.04.2017; Accepted : 14.05.2017

\section{MEMBERS OF THE RESEARCH FORUM}

